\title{
Learning of Poetry Writing High School Students (SMA) : Exploration Study
}

\author{
Sutikno, Retno Winarni, Suyitno, Nugraheni Eko Wardani
}

Pascasarjana Universitas Sebelas Maret Surakarta Jl. Ir. Sutami 36 A Surakarta, Indonesia

\begin{abstract}
Based on the results of the study, it was found that in learning to write poetry, Brebes Regency High School students found problems and needs of teachers and students, namely (1) the importance of developing interesting and fun writing poetry learning, (2) the importance of the knowledge learning process in writing poetry (3) There are still teachers who have not applied the right learning model in learning to write poetry, (4) the importance of using appropriate media in learning to write poetry, and (5) the importance of introducing students to multicultural learning in writing poetry. Based on the analysis of the needs of teachers and students the results needed are needed to develop learning to write poetry as follows: (1) easy to use by high school teachers wherever they are, (2) learning that is active, innovative, creative, effective and fun, and (3) improving social sense between friends and training to dare to write poetry with confidence.
\end{abstract}

Keywords : Learning, Writing Poetry, High School Students

\section{INTRODUCTION}

Learning is at the core of the overall education process. The quality of teaching and learning is determined by all the components involved in it, especially those in the teaching-learning process, namely teachers and students. This can motivate the teacher to improve the role and competence because the teaching-learning process and student learning outcomes are largely determined by the teacher as the facilitator. Teachers must be able to learn well, especially in developing learning plans. Teachers must be able to carry out creative and innovative learning so that they grow creatively (Mulyaningsih, Suwandi, Setiawan, \& Rohmadi, 2018) and have high imaginative power in students who are learning, besides that teachers must be able to provide objective assessments to students.

The success of the teaching-learning process requires the involvement of several elements of teaching, namely teachers, students, subject matter, teaching media, goals, teaching methods, and other supporting facilities. The teaching device cannot stand alone. Each element has its own role in producing the teaching-learning process. Thus, success requires the integrity of each element. The teacher is the main element in learning because the spirit in the classroom in learning is a teacher, it is proper for the teacher to have four teacher competencies, namely pedagogic, professional, personal, and social.

The role of the teacher in teaching and learning activities is not just to convey knowledge to students, but also to provide guidance, direction, motivation, and good character formation. The dominance of teachers in the learning process, especially writing poetry also causes more students not to have a role and passively involved, students are waiting for the offerings from the teacher rather than finding and finding their own knowledge, skills, and attitudes they need. Such conditions do not support the 
improvement of the quality of education, especially the quality of teaching Indonesian in learning to write poetry in schools. Is it true that the failure of learning Indonesian especially in writing poetry is caused by the lack of involvement of students in the teaching-learning process, and the lack of proper teaching-learning principles. It is not right if students are not involved in learning, because learning Indonesian primarily achieves the success of four language skills, namely listening, speaking, reading and writing.

Poetry according to the Horace concept, has utile and dulce functions which are useful and enjoyable or entertaining (Teeuw, 1988). Poetry is useful because the process of its creation is through contemplation of life and life so that there is something that the poet wants to convey through his poetry and something that is useful /useful for the reader. Besides being useful, poetry is also entertaining because it is aesthetic and aesthetic poetry can be enjoyed, among others through diction, imagine, concrete words, a figure of speech, verification, and typography.

Until now poetry writing is done in schools and in a number of universities. This happens because learning to write poetry is recognized as having functions and benefits for human life. Poetry writing learning functions to train students' language skills, namely to train imagination in order to be able to pour ideas so that writing skills become more qualified (Mulyaningsih, 2015). Learning to write poetry in high school aims to improve the ability of students to practice sharpening reasoning, imagination, sensitivity to society, culture, and the environment. The material for writing poetry is found in the learning taught in class $\mathrm{X}$, which is to recognize poetry.
Learning to write poetry has tended to be related to natural conditions and romance, besides that the teacher in delivering poetry writing subject matter paid less attention to students having diverse backgrounds, diverse economic status, different tribes, different religions, and competence in writing poetry which is not the same. Students are not directed to create or write multicultural poetry but tend to write poems that are themed (eg the theme of education, heroism, romance, environment) so that what happens is ignoring pluralism and cultural diversity. The multicultural diversity in the classroom is actually a portrait multicultural picture.

Learning to write poetry is an aspect of skill that directs students to practice creative writing. Poetry is a description of various social events, regarding fraud, insult, betrayal, robbery, theft, seizure, desecration, and so on. In addition, the poem also describes joyful events, matters of help, agreement of friendship, romance and so on. These various social events are multicultural phenomena that are interrelated in the student environment, for which learning to write poetry needs to elevate cultural or multicultural diversity in the student environment.

Poetry gives us about human knowledge as social beings, who are involved in social problems. Imaginatively poetry can interpret basic human situations, which can be suffering from injustice, struggle for power, human conflict with fellow human beings, rebellion against God's law or human law itself. Humans as social beings and cultural beings are basically influenced by human values. These values are in the form of ethics that are closely related to morality and aesthetics that are associated with a sense of beauty (Ismawati, 2013).

Learning to write poetry needs to be developed so that students have a high awareness in determining 
the most appropriate choices as life guidance in the future with various communication tools. One of them is by integrating on Indonesian language subjects. Thus, learning Indonesian is a medium that can bridge through creative writing skills in high school (SMA) needs to be done because students live in diverse communities. In accordance with the purpose of learning to write poetry, namely to improve students' ability to appreciate literature, multicultural phenomena need to be presented.

Based on the observation of learning from five high schools in Brebes district namely Brebes High School 3, Wanasari High School, Larangan High School, Bulakamba High School, Tanjung High School, it was observed that the quality of learning to write poetry was thematic, and of poor quality. The implementation of learning to write poetry is still dominated by teachers or teacher-centered. Teachers use the lecture method more and theorize, while the condition of students is known to be less active and less interested in learning to write poetry. Students assume that writing poetry is not useful to prepare for their future, so students are less active in issuing their ideas in the practice of writing poetry, besides the situation and condition of students in participating in learning to write poetry is not conducive. Students who sit behind tend to be less concentrated in listening to the teacher's explanation because it begins to not like the practice of writing poetry.

Based on this background, a dissertation study was carried out with the title "Development of Poetry Writing Learning Based on Multicultural Education with the Synectic Model of Brebes Regency High School students" who followed the ten steps of research and development proposed by Borg \& Gall (1988) which later by Sukmadinata (2012) modified into four stages, including the exploration phase, development of prototype models, model testing, and dissemination. This paper is part of the research on developing the learning model, namely the exploration phase. The objectives of the exploration phase are (1) Assessing the existence and quality of learning instruments to write poems including syllabus, learning implementation plans, (2) Knowing the poetry writing learning model so far, (3) Assessing the level of teacher needs related to learning to write poetry.

\section{METHODS AND MATERIAL}

This study uses a qualitative naturalistic descriptive form, namely research whose data is in the form of words, images, and not numbers (Moleong, 2010)The researcher collects as much information as possible related to (1) Planning learning to write poetry in five Brebes district high schools, (2) Implementation of learning to write poetry in five Brebes district high schools, (3) Assessment of poetry writing learning in Brebes high school district. Data collection techniques using observation, interviews, and document analysis.

Observations carried out in a planned and controlled manner by conducting direct observations of the learning process of writing poetry in the classroom. Interviews were carried out structurally with a teacher and student respondents regarding the implementation of learning to write poetry. The collected data was analyzed using the working principle of an interactive analysis model consisting of three activity lines, namely data reduction, data presentation, and drawing conclusions or verification. Data reduction is done by simplifying data obtained from field notes. The goal is to reinforce, shorten, and discard the important things and arrange data in such a way that the conclusions of the research can be done. Data that has been reduced, presented. The next stage is making conclusions. 
The study was conducted in five high schools in Brebes district, namely Brebes High School 3, Wanasari High School, Larangan High School, Tanjung High School, Bulakamba High School. The study was conducted in the odd semester of 20152016.

\section{RESULTS AND DISCUSSION}

From the preliminary study found two main problems, namely (1) Problems and needs of teachers in the learning process of writing poetry, and improving learning the learning process of writing poetry, (2) Problems and needs of students in the learning process of writing poetry. Exploration is done to gather information and get input through direct observation and observation, as well as interviews with teachers and students, in five high schools in the Brebes district.

Observation and interview about poetry writing learning for high school students that researchers did for four months starting April to August 2015 in five Brebes high school districts, namely: (1) 3 Brebes public high school, (2) 1 Wanasari public high school, (3) Public high school 1 Bulakamba, (4) 1 Tanjung public high school, (5) Public high school 1 Larangan. During this exploration phase, researchers conducted an in-depth study of the implementation of poetry writing learning in five high schools in the Brebes district. The purpose of the exploration activity is to obtain a comprehensive description of the conditions of learning to write poetry, the needs of students, and the needs of teachers about multicultural educationbased poetry writing learning models with synectics The exploration results in this study were obtained through observation, interviews, and documents about learning models writing poetry as follows like this.

\section{Analysis of Teacher's needs}

Problems and needs of teachers and students in learning to write poetry in high school through observation or observation, and interviews. Based on the results of observations and interviews with teachers and students, there are many findings of problems faced by teachers and students in learning to write poetry in high schools in Brebes district, Central Java.

After the researcher conducted an interview with the teacher who teaches Indonesian language subjects and observes the teacher's administration in the classroom, among others, it relates to (1) compiling a lesson plan for writing poetry; (2) application of learning procedures; (3) the application of learning resources and media. First The problems and needs of the teacher in the preparation of the learning implementation plan (RPP) write poetry in high school. Every semester the teacher prepares a learning implementation plan (RPP), which is felt in the preparation of the learning implementation plan is a unique problem for teaching teachers in Indonesian subjects as stated by Rtn, Sc, El, SM, teacher, informant. Based on the results of interviews with informants (teachers) the five of them in learning each semester always make a learning implementation plan (RPP) in accordance with the conditions of the students, and always improve the learning implementation plan (RPP) each subsequent semester. Informant also said almost the same that in compiling the plan for implementing the learning to write poetry varied and many had difficulties.

The difficulty of the teacher in preparing the learning plan is the initial implementation of the 2013 curriculum in Brebes Regency, so there is still doubt, this is because not all teachers of Indonesian language subjects fully understand the application of the 2013 
curriculum from planning, learning, and assessment, besides the 2013 curriculum always has improvements. This was revealed by the teacher in the interview notes, that the teacher (the informant) had difficulty compiling a learning implementation plan because the planning of the KTSP curriculum learning was very different, the informant explained, still confusing understanding $\mathrm{KI} 1, \mathrm{KI} 2, \mathrm{KI} 3$, and $\mathrm{KI}$ 4 especially write down the steps of teaching-learning activities.

In line with what was revealed by the teacher Sc, he explained that the preparation of the 2013 curriculum implementation plan was more difficult than the preparation of the KTSP learning implementation plan. This was explained by the informant because it was difficult to connect and choose KI besides the basic competency translation must be written in full. The problem expressed by the informant (teacher) Ela, which is related to the preparation of a plan for implementing learning about writing poetry, is very difficult to sort out from KI, Basic Competence, Indicators, let alone describe teaching and learning activities. Many teachers felt that delivering poetry writing material received less attention. The teacher said (Tk) "That I myself do not like literary learning material especially writing poetry" then informant explained that when it came to the practice of writing poetry it was difficult to choose beautiful words and find ideas in the practice of writing poetry so that when I delivered writing material My children's poetry told me to explore the practice of writing poetry, sometimes students get out of class to get imagination.

Based on the results of classroom learning observations relating to learning to write poetry, the informants (teachers) were less ready to deliver poetry writing learning material. This was demonstrated by (Ela) the implementation of learning was conventional, meaning that the teacher still dominated learning, besides learning to write dominant poetry in children told to read poetry in the textbook, even though the main material is writing poetry. The results of observations in other schools found that the informant (teacher) seemed nervous in starting the learning process of writing poetry, seemed troublesome to start learning, the teacher was not coherent in conveying the implementation of the learning process, from the implementation the learning process can be concluded that the teacher is less prepared to deliver learning material this because the teacher does not prepare a plan for implementing learning to write poetry so that in the process of implementing learning it seems unprepared.

The informant (the teacher) in preparing the learning implementation plan (RPP) felt that he had been directed and in accordance with the 2013 curriculum but sometimes still felt less confident that the lesson plan he had made was in line with what was expected in the 2013 curriculum, so the informant always tried to improve the implementation plan learning (RPP) well, asking fellow Indonesian language teachers in the same school also asked teacher friends when there was a subject teacher discussion meeting (MGMP).

Secondly, the problems and needs of teachers in the application of learning procedures for writing poetry of high school students. The problem is also faced by teachers in the learning process that is related to the application of learning procedures for writing poetry, researchers find observations in class namely class $\mathrm{x}$ public high school 3 Brebes, public high school 1 Bulakamba, Tanjung public high school, state high school Prohibition, and state senior high school 1 The findings have almost the same problem, namely the application of learning procedures. Dominant teachers in applying poetry writing learning students are invited to read poetry in textbooks, students are given 
less opportunity to creativity in exploring the learning process of writing poetry, the practice of writing poetry tends to be of the same theme.

The findings of the researchers in conducting classroom observations, teachers (Rt) in the implementation of the learning process of writing poetry began with an explanation of the theory of poetry. The teacher conducts questions and answers about the material to be delivered, the teacher motivates students that writing can practice creativity also adds confidence to writing. The teacher gave examples of poetry works. Another problem related to the interaction of the teacher and students was found by the teacher (Ela) starting by directly reading poetry in the class so the students were shocked full of question marks about what material this morning, after the teacher finished reading a poem the teacher explained about the theory of how to write good poetry. The researcher found that in the implementation of the learning process the teacher paid little attention to the introduction of learning.

From the observation findings when the learning took place it turned out that the teachers in the learning process of writing poetry were still dominated by the teacher, the students were not given the opportunity to explore based on their creativity. In addition, even though the material is about writing poetry, it is still the dominant explanation and example of poetry reading in the textbook. Related to the utilization of the teacher's time to learn by giving homework about writing poetry, thus when researchers conduct learning observations the teacher tends to discuss the theory of writing poetry. The teacher (informant) always gives the task of writing poetry individually after the poetry writing material has finished.

Third, the problems and needs of teachers in determining the media and sources of learning to write poetry. The media and learning resources are very helpful in the learning process because it will help students more quickly understand the learning material. Researchers conduct observations in several learning media schools are considered less important. This is indicated by the teacher not using visual media, audio media, especially audio-visual media. After the researchers interviewed several informants (teachers) they felt troubled and difficult if teaching had to prepare many things including preparing learning media. Other findings in the same place there are still students who are less focused on learning to write poetry so the class is rather noisy. This researcher found that the absence of media made the concentration of students less focused and less attractive. According to the informant (Tk) when delivering poetry writing material, never used the media but students introduced nature or the environment as a direct media to get poetry writing imagination.

The source of learning is found to be monotonous, that is, only struggling from the source of textbooks or textbooks, the teacher does not give the opportunity to students that the source of learning related to writing poetry is very much including the universe, magazines, journals and so on.

Fourth, the problem of learning material in writing poetry, based on the results of interviews with dominant informants (teachers), teachers lack understanding of multicultural based learning, especially learning to write poetry based on multicultural learning. As stated by Informant (Rt) I have heard of multiculturalism but in literary learning especially writing poetry has never been applied, the informant did thematically according to the mandate of the 2013 curriculum. There was also a word multicultural but never applied in learning. Indonesian mainly writes poetry. Informant (St) said 
that multicultural based learning had never been applied in learning, especially writing poetry, so it still felt strange. The statement of the informant (Tk) has clearly never practiced multicultural education-based learning, let alone learning to write poetry. Informant said that what was known to be multicultural was related to culture, for example, Javanese cultures such as the seven months of a woman who was pregnant from which students were told to write poetry. Thus the informant explained that learning to write poetry is still thematic.

The five problems and needs of the teacher relate to the application of the model, based on the results of interviews with several informants in learning, have implemented learning models, but completely have not applied syntax in a coherent manner according to the model used. Some informants explained almost the same name the teacher had practiced the learning model even though it was not obedient to the syntax, besides the teacher (informant) did not understand what model I applied to the students, the informant thought that the child was active and could write poetry easily and with quality. In addition, in general, the informant said that the synectic model had never been applied, even though it had only been heard of the synectic model.

According to the information statement (Sc), I have often applied the learning model but the synectic model does not understand at all, besides the application of the model sometimes arises from its own ideas which are important for children to understand well. In line with informant (St), I applied to learn outside the classroom to see nature and the environment, and then students started writing poetry, I did not understand what the model was going on, moreover the synectic model did not understand, I hope there will be examples of learning to write poetry based on multicultural with a synectic model. The same statement was conveyed by informant (Tk) students I often invited out of class to see the scenery to get imagination so that students easily practice writing poetry only that but do not understand what model or name is used, but informants do not expect syntax clearly. Regarding the informant's synectic model, he just heard, honestly the informant had never applied the synectic model in learning to write poetry.

\section{Analysis of Student Needs}

First, the problems and needs of high school students in Poetry Writing Learning. Based on the results of interviews and observations in the learning process in the classroom, the researcher found various problems as follows: (1) The majority of students said learning to write poetry was fun but for students it was difficult to find ideas or ideas, students found it difficult to choose beautiful words, especially enter figure of speech. Based on what was conveyed by students from several schools proving that learning to write poetry was felt fun but difficult and difficult, according to what was expressed by students (Dani) literary learning was fun but "learning to write poetry I did not like because I could not express ideas or ideas, and the difficulty of choosing beautiful words. " Similar to what was expressed by students (Jono) from different schools "learning to write poetry has been studied since elementary school, junior high school but in high school learning to write poetry still finds it difficult to pour die or ideas, and choose the right words for poetry. Also revealed by students (Siti) from a different high school".

Learning to write poetry is fun but to pour die or difficult ideas. From some expressions, students from different schools prove that learning to write poetry is fun but difficult and precise. (2) Writing poetry is difficult for non-talented students. The next finding is 
the problem of students' interests and talents said to greatly affect the success of students in the practice of writing poetry, this is proven by several expressions from students, among others; students (Mira) "said that whenever there is literary material, especially writing poetry, I do not have the enthusiasm to follow class learning because I do not have the talent to write poetry, difficult to express ideas or ideas, let alone choose the right and beautiful words so that every time I write poetry the results are not good ". As expressed by students (Dani) from high school different" my talent is music so it seems not interested in learning to write poetry ". Students (Ani) revealed, "actually I like to write poetry but I don't have the talent to write poetry". In accordance with the expressions of the informants (students) talents are said to determine the success of students in learning to write poetry. (3) Learning to write poetry does not interest many students. With regard to learning to write poetry that is not in demand by students is a challenge for Indonesian teachers, according to the expressions of high school students (Tatik) "Every learning to write poetry students feel unhappy because they are considered to be a waste of time and has no benefit". Students (Hari) also revealed the same problem "learning to write poems is useless is just a waste of time". Different high school students (Kiswanto) revealed "learning is important both knowledge, skills, and attitudes, but the knowledge that can be for the future of life while learning to write poetry cannot guarantee success in life".

\section{CONCLUSION}

From result and analysis can be conclus that (1) the importance of developing interesting and fun writing poetry learning, (2) the importance of the knowledge learning process in writing poetry (3) There are still teachers who have not applied the right learning model in learning to write poetry, (4) the importance of using appropriate media in learning to write poetry, and (5) the importance of introducing students to multicultural learning in writing poetry. Based on the analysis of the needs of teachers and students the results needed are needed to develop learning to write poetry as follows: (1) easy to use by high school teachers wherever they are, (2) learning that is active, innovative, creative, effective and fun, and (3) improving social sense between friends and training to dare to write poetry with confidence.

\section{REFERENCES}

[1]. Borg, W. R \& Gall, M. D. (1988). Educational Research: An Introduction. New York: Longman.

[2]. Ismawati, E. (2013). Pengajaran Sastra. Yogyakarta: Ombak.

[3]. Moleong, L. J. (2010). Metode Penelitian Kualitatif. Edisi Revisi. Bandung: Remaja Rosdakarya.

[4]. Mulyaningsih, I. (2015). Sastra Anak: Pengembangan Kreativitas melalui Puisi dan Pantun. Cirebon: Nurjati Press.

[5]. Mulyaningsih, I., Suwandi, S., Setiawan, B., \& Rohmadi, M. (2018). PARMI (production, attention, retention, motivation, and innovation): An alternative to improving scientific writing skills. Lingua Cultura, 12(4), 317-321. https://doi.org/10.21512/lc.v12i4.4159

[6]. Sukmadinata, N. S. (2008). Metode Penelitian Pendidikan.Bandung: PT Remaja Rusdakarya

[7]. Teeuw, A. (1988). Sastra dan Ilmu Sastra: Pengantar Teori sastra. Cet. Ke 2. Jakarta : Pustaka Jaya.

\section{Cite this article as :}

Sutikno Retno Winarni, Suyitno Nugraheni Eko Wardani, "Learning of Poetry Writing High School Students (SMA) : Exploration Study", International Journal of Scientific Research in Science and Technology (IJSRST), Online ISSN : 2395-602X, Print ISSN : 2395-6011, Volume 6 Issue 5, pp. 18-25, September-October 2019. Available at doi : https://doi.org/10.32628/IJSRST196475 Journal URL : http://ijsrst.com/IJSRST196475 